\title{
Radioprotection : les défis de l'open access
}

La Déclaration de Berlin sur le libre accès aux connaissances en sciences et sciences humaines a lancé en 2003 le libre accès aux publications scientifiques, c'est-à-dire la pratique consistant à fournir un accès en ligne à des informations scientifiques gratuites pour l'utilisateur et réutilisables (Déclaration de Berlin, 2003).

En 2012, l'éditorial du premier numéro de Radioprotection intitulé «Radioprotection et Open Access » soulevait des questions pour notre journal (Métivier et al., 2012) : coût de la publication papier, prépublication dans des archives ouvertes (Open Access Green), open access résultant du paiement par les auteurs (Open Access Gold). La décision fut prise d'avoir un système d'Open Access hybride et de mettre en accès libre tous les articles deux ans après leur publication.

Ensuite, la Commission européenne a publié une recommandation sur l'accès et la préservation de l'information scientifique (Commission européenne, 2012).

En 2018, le Plan S était une initiative de publication scientifique en libre accès lancée par «cOAlition S », un consortium d'agences de recherche nationales et de bailleurs de fonds de douze pays européens (Plan S, 2018). Le Plan S intitulé «Accélérer la transition vers un libre accès complet et immédiat aux publications scientifiques » impose aux scientifiques et chercheurs, qui bénéficient de financements de la recherche grâce à des subventions publiques fournies par les conseils nationaux et européens de la recherche et les organismes et institutions de financement, de publier leurs travaux dans des revues en libre accès ou sur des Plateformes Open Access, conformes et accessibles à tous d'ici 2021. La question est bel et bien là mais elle s'avère beaucoup plus complexe que prévu en termes d'équilibre budgétaire de notre revue!

Par ailleurs, nous avons le plaisir de constater que le facteur d'impact de la revue Radioprotection a augmenté au cours des dernières années et atteint 1,015 en 2020 (0,541 en 2019). Nous sommes très reconnaissants à tous les scientifiques qui ont soumis et publié dans notre journal ainsi qu'à tous les rédacteurs associés et relecteurs pour leur travail acharné. Nous avons également observé que sept articles ont contribué majoritairement à l'augmentation du facteur d'impact:

- tous ces articles ont été publiés en Open Access ou en accès libre;

- quatre articles traitaient de situations post-accidentelles (Bertho et al., 2019; Bottollier-Depois et al., 2019; Lochard et al., 2019; Schneider et al., 2019);

- deux articles traitaient de problématiques de radiothérapie (Cosset et al., 2018; Thellier, 2019);

- un article portait sur l'exposition aux rayonnements non ionisants (Point, 2018).

Ces constats confirment la pertinence de notre politique éditoriale concernant les articles ciblant les problématiques postaccidentelles et les expositions médicales. Ils confirment également l'influence majeure et positive de l'Open Access sur le facteur d'impact de notre revue.

Pour conclure, une réflexion est à mettre en place avec l'éditeur EDP Sciences et avec la SFRP (Société Française de Radioprotection) en vue de l'adoption de la publication de tous les articles en Open Access. De même, le maintien de la version papier ainsi que le respect des intérêts des membres de la SFRP restent des questions en suspens. Des décisions devraient être prises dans les prochains mois.

Enfin, la qualité de notre revue et l'augmentation récente de notre facteur d'impact dépendent de la qualité des manuscrits soumis. Ce succès est donc aussi le succès de nos auteurs et vos projets de manuscrits sont toujours les bienvenus à Radioprotection.

\section{Radioprotection: the challenges of open access}

The Berlin Declaration on Open Access to Knowledge in the Sciences and Humanities launched in 2003 the Open Access to scientific publications, i.e., the practice of providing online access to scientific information that is free of charge to the user and is reusable (Berlin Declaration, 2003).

The editorial of the first issue of Radioprotection in 2012, entitled "Radioprotection et Open Access", raised questions for our journal (Métivier et al., 2012): printing costs, pre-publication in open archives (Open Access Green), open access resulting from payment by the authors (Open Access Gold). Decision was made to adopt a hybrid Open Access plus a free access to all articles after two years. 
Then, the European Commission published a recommendation on access to and preservation of scientific information (European Commission, 2012).

In 2018, the Plan S was an initiative for open-access science publishing launched by "cOAlition S", a consortium of national research agencies and funders from twelve European countries (Plan S, 2018). The Plan S entitled "Accelerating the transition to full and immediate Open Access to scientific publications" requires scientists and researchers who benefit from research funding by public grants provided by national and European research councils and funding organizations and institutions to publish their work in compliant Open Access Journals or on compliant Open Access Platforms that are available to all by 2021. The issue is definitely there, although it appears to be much more complex than anticipated from the economic point of view!

On another hand, we have the pleasure to observe that the impact factor of Radioprotection has increased during the past years and has reached 1.015 in 2020 (0.541 in 2019). We are very grateful to all scientists who have submitted and published in our journal and to all associate editors and referees for their hard work. We have also observed that seven articles contributed mostly to the rise of the impact factor:

- all these articles were published in Open Access or free access;

- four articles were dealing with post-accidental situations (Bertho et al., 2019; Bottollier-Depois et al., 2019; Lochard et al., 2019; Schneider et al., 2019);

- two articles treated radiation therapy issues (Cosset et al., 2018; Thellier, 2019);

- one article was on non-ionizing radiation exposure (Point, 2018).

These observations confirm the relevance of our editorial policy regarding articles targeting post accidental issues and medical exposures. They also confirm the major and positive influence of Open Access on the impact factor of our journal.

To conclude, the adoption of publication of all articles in Open Access is an issue to be addressed together with the editor EDP Sciences and with SFRP (the French society of radiological protection). Other pending questions are to maintain the paper version of the journal and to properly keep and serve the interests of the SFRP members. Decisions need to be taken in the next months.

Finally, the quality of our journal and the recent rise of our impact factor depend from the quality of the submitted manuscripts. Therefore, this success is also the success of our authors and your manuscripts are always very welcome in Radioprotection.

\section{Références}

Berlin Declaration on Open Access to Knowledge in the Sciences and Humanities. 2003. https://openaccess.mpg.de/Berlin-Declaration.

Bertho JM, Maître M, Croüail P, Naito W, Shkliarava N, Mostovenko A, Jones K, Simon-Cornu M. 2019. Assessment of population radiation exposure at the edge of the exclusion zone 32 years after the Chernobyl accident: methods and preliminary results. Radioprotection 54(4): 247-257. https://doi.org/10.1051/radiopro/2019041.

Bottollier-Depois JF, Allain E, Baumont G, Berthelot N, Darley G, Ecrabet F, Jolivet T, Lebeau-Livé A, Lejeune V, Quéinnec F, Simon C, Trompier F. 2019. The Open Radiation project: monitoring radioactivity in the environment by and for the citizens. Radioprotection 54(4): 241-246. https://doi.org/10.1051/radiopro/2019046.

Cosset JM, Hetnal M, Chargari C. 2018. Second cancers after radiotherapy: update and recommandations. Radioprotection 53(2): 101-105. https://doi.org/10.1051/radiopro/2018015.

European Commission. 2012. Commission Recommendation of 17 July 2012 on access to and preservation of scientific information (2012/417/ EU). Off. J. Eur. Union 194: 39-43.

Lochard J, Schneider T, Ando R, Niwa O, Clement C, Lecomte JF, Tada JI. 2019. An overview of the dialogue meetings initiated by ICRP in Japan after the Fukushima accident. Radioprotection 54(2): 87-101. https://doi.org/10.1051/radiopro/20190212019.

Métivier H, Lallemand J, Henri A. 2012. Radioprotection et Open Access. Radioprotection 47(1): 11-12. https://doi.org/10.1051/radiopro/ 2012007.

Plan S. 2018. Accelerating the transition to full and immediate Open Access to scientific publications. Science Europe. https://web.archive.org/ web/20180904122211/https://www.scienceeurope.org/wp-content/uploads/2018/09/Plan_S.pdf.

Point S. 2018. Blue Light Hazard: are exposure limit values protective enough for newborn infants? Radioprotection 53(3): 219-224. https://doi. org/10.1051/radiopro/2018025.

Schneider T, Maître M, Lochard J, Charron S, Lecomte JF, Ando R, Kanai Y, Kurihara M, Kuroda Y, Miyazaki M, Naito W, Orita M, Takamura N, Tanigawa K, Tsubokura M, Yasutaka T. 2019. The role of radiological protection experts in stakeholder involvement in the recovery phase of post-nuclear accident situations: Some lessons from the Fukushima-Daichi NPP accident. Radioprotection 54(4): 259-270. https://doi.org/ 10.1051/radiopro/2019038.

Thellier S. 2019. Risk analysis in radiotherapy. Part 2: From failure modes to success modes, a paradigm shift. Radioprotection 54(1): 21-30. https://doi.org/10.1051/radiopro/2019003. 